Within Werner Bjerge NW-SE striking faults separate the (?) Carboniferous and Permian rocks from Upper Permian and lowermost Triassic strata. The main faults are possibly late Palaeozoic faults reactivated in Tertiary time.

\title{
References
}

Aellen, M. (in press). Geological map of the Gurreholms Bjerge and surrounding area east of Schuchert's Flod Northwest Jameson Land, East Greenland $71^{3 / 4}{ }^{\circ}$ N. Meddr Gronland 171, 3.

Bearth, P. 1959: On the alkali massif of the Werner Bjerge in East Greenland. Meddr Grenland 153, 4, 63 pp.

Birkelund, T. \& Perch-Nielsen, K. 1969 : Field observations in Upper Palaeozoic and Mesozoic sediments of Scoresby Land and Jameson Land. Rapp. Gronlands geol. Unders. 21, 21-35.

Birkelund, T., Håkansson, E. \& Surlyk, F. (in press) New finds of Bathonian, Callovian, and Oxfordian ammonites in northern Jameson Land, East Greenland. Meddr dansk geol. Foren. 20.

Callomon, J. H. (in press) Map 1:100 000. Meddr Gronland 168, 4.

Grasmück, K. \& Trümpy, R. 1969: Notes on Triassic stratigraphy and paleontology of north-eastern Jameson Land (East Greenland). Meddr Grønland 168, 21, 5-71.

Heinberg, C. (in press) Some Jurassic trace fossils from Jameson Land (East Greenland). Geol. J. (Special Vol.).

Kleiber, K. 1944: Beitrag zur Geologie und Sedimentpetrographie Ostgrönlands. Meddr Grønland 115, 4, 148 pp.

Kempter, E. 1961 : Die jungpaläozoischen Sedimente von Süd Scoresby Land. Meddr Grønland 164, 1, $123 \mathrm{pp}$.

Witzig, E. 1954: Stratigrapische und tektonische Beobachtungen in der Mesters Vig-Region (Scoresbyland, Nordostgrönland). Meddr Grønland 72, Afd. 2, 5, 26 pp.

\section{PRELIMINARY REPORT OF THE MAPPING OF THE BASALT AREA, SOUTH SCORESBY SUND}

\author{
W. Stuart Watt
}

Within the basalt area field activity in 1969 was concentrated mainly on the eastern part of Milne Land and extended over more scattered localities in the vicinity of Vikingebugt. On Gåseland a single traverse was made at Knækket.

\section{Milne Land}

Tertiary basalt covers the higher parts of eastern Milne Land (fig.6). The main part overlies gneisses directly, but to the east basalt lies on outliers of Jurassic sandstones which thin westwards. Basalts also cap the tops of Bays Fjelde. 


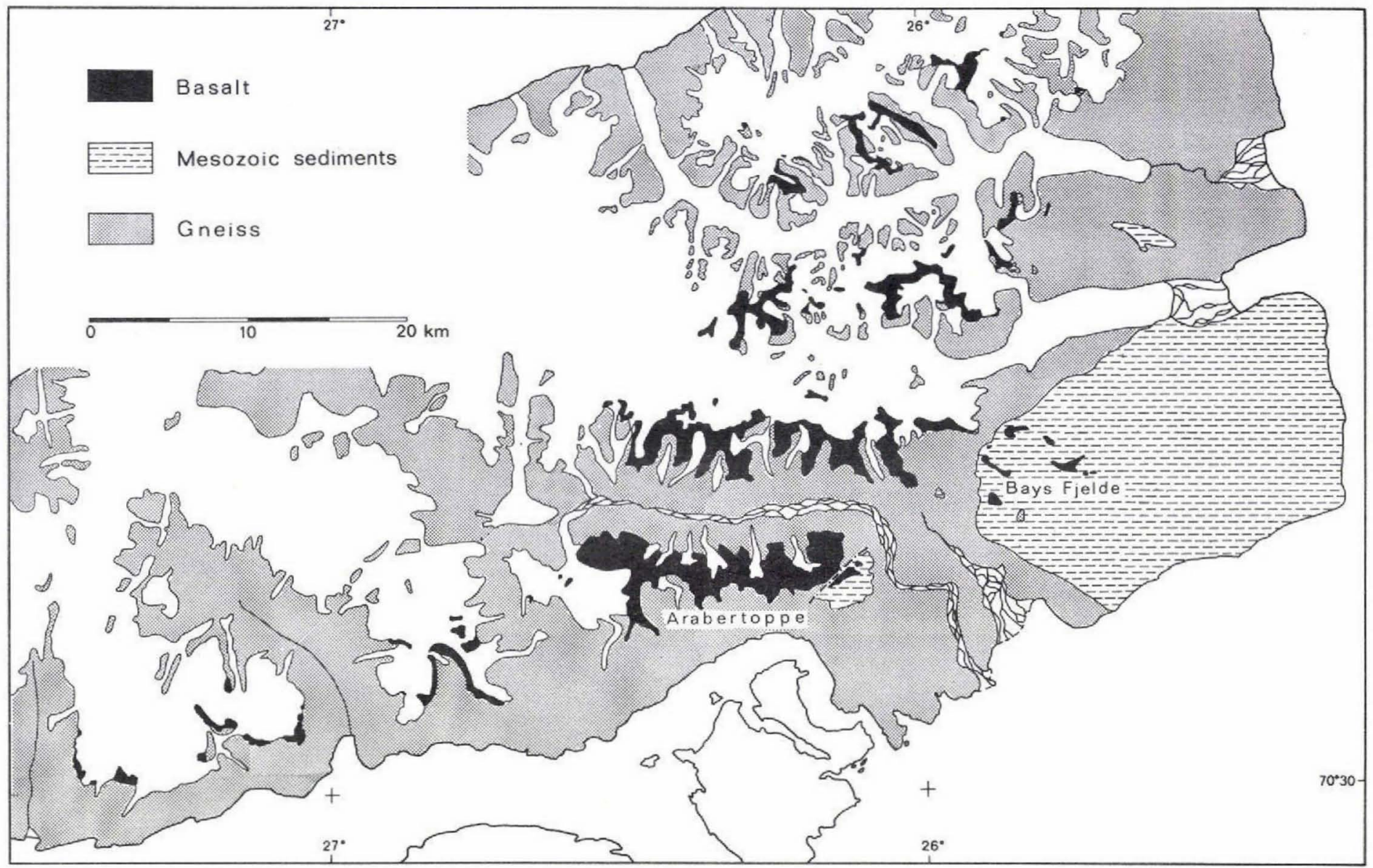

Fig. 6. Sketch map of the extent of the Tertiary basalts on Milne Land, Scoresby Sund. 
Basalt

The base of the basalts rises from $600 \mathrm{~m}$ in the south to $1800 \mathrm{~m}$ in the north which gives an average slope of $2.5^{\circ}$ southwards. A preliminary drawing of contours on the base of the basalt suggests that east-west trending faults have affected the basalts. Dip measurements on individual flows, made on aerial photographs, vary from flat-lying to $2^{\circ} \mathrm{S}$. Faulting of the basalts has only been confirmed at the eastern end of Arabertoppe where a NE-trending normal fault has down-faulted the basalt to the SE about $80 \mathrm{~m}$ by rejuvenation of an earlier fault line. Landslips in the basalts are seen locally on steep cliff faces, particularly where basalt overlies sandstone.

Jurassic sandstones

The Jurassic sandstones underlying the basalts at Bays Fjelde consist of a lower, unfossiliferous, pale yellow weathering, coarse-grained sandstone (Aldinger's (1935) Charcot Bugt sandstone) overlain by a ferruginous sandstone containing, at least locally, ammonites, belemnites and lamellibranchs. One fossiliferous locality yielded the ammonites Prorasenia bowerbanki Spath and Amoeboceras sp. of Lower Kimmeridgian age, another locality gave Cardioceras aff. zenaidae of Upper Oxfordian age (Spath, 1935).

\section{Dykes}

Dolerites dykes are comparatively numerous in the sandstone area, but rare in the gneisses and basalts. Two trend directions are characteristic in the sandstone area E-W and NW-SE.

A small agglomerate vent, about $6 \mathrm{~m}$ in width, can be followed for $400-500 \mathrm{~m}$ cutting a basalt ridge north-west of Bays Fjelde. The agglomerate consists of blocks of garnetiferous gneiss up to $30 \mathrm{~cm}$, similar to the gneiss underlying the basalt ridge.

Inter-basaltic sediments

Thin horizons of inter-basaltic sediments were encountered at several localities in the eastern part of Milne Land. They average only $0.5 \mathrm{~m}$ in thickness and are often discontinuous. They mostly consist of buff-coloured, coarse-grained sandstone sometimes accompanied by shaly coal and charcoal wood. Pieces of silicified wood were frequently seen though mostly in the scree.

The sandstones are largely composed of quartz grains with occasional grains of garnet and magnetite as well as basalt pebbles. The distribution of sandstone horizons is too sporadic for more than very local correlation.

\section{Pyroclastic deposits}

Pyroclastics appear at the base of a section in central Milne Land where they dip steeply to the north. They comprise blocky bombs up to head-size with a chilled 
crust. Scattered traces of pyroclastics were also seen along the fault zone in southern Milne Land.

Traces of thin tuff horizons were seen in a number of places but rarely exceed 2$4 \mathrm{~cm}$ in thickness. Some contain small mineral particles visible to the naked eye, often with flow lineation.

\section{Sydbræ - Borgvig region}

A number of traverses were made along the southern coast of Hall Bredning from Borgvig, where the basalt reaches sea level, to a locality west of Sydbræ where it is seen overlying basement gneisses just above sea level. Scattered traverses were made inland from Vikingebugt on both sides of Bredegletscher. The location of place names is shown in fig. 1 .

Dip measurements show that the basalts dip 1 to $4^{\circ} \mathrm{SSE}$, steepest along the coast near Vikingebugt.

\section{Basalt}

Two distinct "grey series" appear in the otherwise very uniform basalt succession in the region south of Vikingebugt. They can be traced on aerial photographs along the nunataks at least as far westwards as Sydbræ. The higher of the "grey series" can only be seen on the high inland nunataks. The outcrops show a rounded, grey weathering with horizontal, very amygdaloidal bands $10-30 \mathrm{~cm}$ in width.

\section{Dykes}

Dykes with an ESE trend cut the basalts east of Sydbræ, and with E-W and NW-SE trends those west of Sydbræ. They average $8-10 \mathrm{~m}$ in width and are vertical; they are doleritic and show signs of multiple intrusion.

\section{Pyroclastic deposits}

Extensive pyroclastic deposits occur in the immediate vicinity of Vikingebugt at several levels. Grading in some deposits is common. While the average size of bombs is about $10 \mathrm{~cm}$ there are occasional bombs measuring up to $1 \mathrm{~m}$ across. The bombs are mostly blocky with a chilled crust but good examples were seen of 10 cm long uniplanar fusiform bombs.

The most extensive deposit visited is at Helgenæs (on the east side of Vikingebugt) where an approximately $50 \mathrm{~m}$ thick pile is cut by thin, chilled basalt sheets.

\section{General remarks}

Throughout the whole region the lava flows are remarkably thick compared with other basalt provinces. In many sections the average flow thickness is in the order 
of $35 \mathrm{~m}$, and locally the average reaches $60 \mathrm{~m}$ with individual flows exceeding 80 $\mathrm{m}$. The base of each flow normally lies on a plane surface, irregularities in the underlying flow being filled with basalt breccia later cemented by zeolitic material.

\section{Composition of the basalts}

The basalt area so far investigated is dominated by tholeites with normative hypersthene and quartz, but the "grey series" is undersaturated with 6 per cent normative olivine and only contains silica-poor amygdale minerals.

Petrographically most flows are fine-grained, intergranular, commonly glomeroporphyritic, usually feldspar-phyric but occasionally also with clinopyroxene phenocrysts. Where plagioclase of the groundmass appears as long, thin needles they often show a marked flow texture.

The "grey series" is generally coarse-grained, part of the group showing clusters of feldspar phenocrysts up to $2.5 \mathrm{~cm}$ across, but occasional flows may be described as pegmatitic.

\section{Amygdale mineral zones.}

Preliminary results show that amygdale mineral zoning is present in the area. A section at Knækket on the south side of Gåseland shows the zoning most clearly within a single profile (fig. 7). Chalcedony with associated mordenite is here found up to $1000 \mathrm{~m}$ above sea level while among the silica-poor minerals analcite in association with chabazite and calcite reaches an altitude of approximately $1200 \mathrm{~m}$. Above this height only chabazite and thomsonite were seen. Above $1700 \mathrm{~m}$ in central Milne Land chabazite is the dominant amygdale mineral with subordinate calcite and levynite, while at the top of a section by Bredegletscher, which lies stratigraphically higher (?) than the basalts to the north there is chabazite and thomsonite. Higher habits of chabazite (habit 3 of Walker, 1951) occur alone in the higher parts of the section by Bredegletscher, but in association with thomsonite it is normally of habit 2 .

\section{Palaeomagnetism of the basalts}

During the mapping of the basalts the magnetic direction of many of the flows was measured in the field with a hand compass. Tests for the magnetic direction were made at approximately 180 sites in profiles on Milne Land, Gåseland, and in the area south of Gåsefjord from Sydbræ to Borgvig (fig. 8). The test localities range in altitude from sea level to $2000 \mathrm{~m}$. 50 per cent of these showed a reverse direction of magnetisation, 36 per cent normal while 16 per cent gave no information as the samples were not sufficiently magnetic to deflect the compass needle; the remain- 


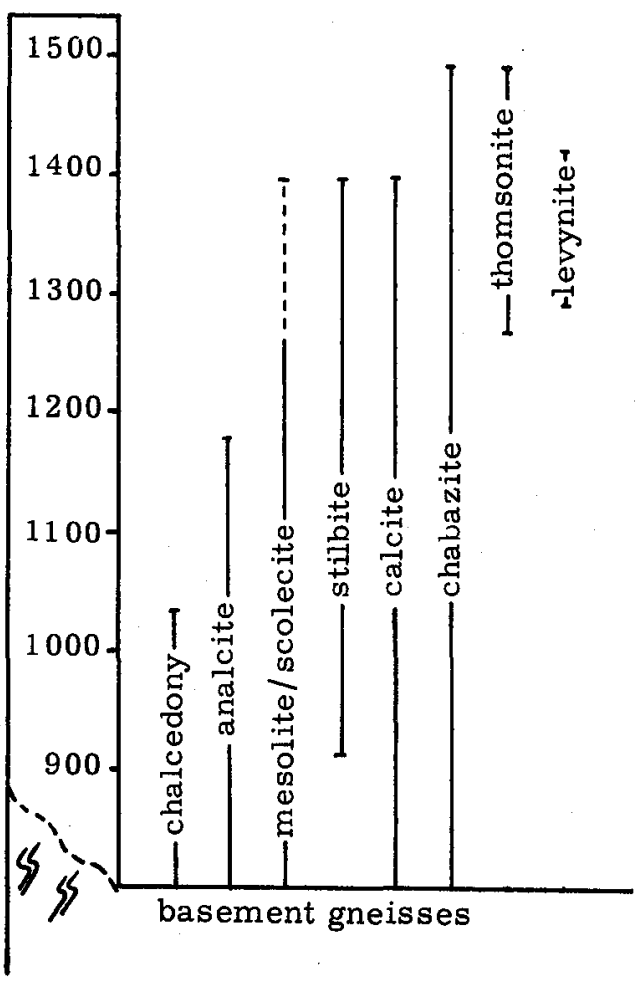

Fig. 7. Altitudinal range in metres of different amygdale minerals at Knækket on Gåseland.

ing 8 per cent were anomalous. The Milne Land profiles show a dominantly reverse magnetisation direction but a few single flows or small zones are normal. The section above Knækket on Gåseland is dominantly reversely magnetised with a single flow at $990 \mathrm{~m}$ and a group between 1300 and $1400 \mathrm{~m}$ that are normally magnetised. These two zones can possibly be correlated with similar groups west of Sydbræ at lower levels. This correlation implies a south-easterly dip of about $2.5^{\circ}$. which is fairly consistent with the dip of the flows in the region. A similar grouping of normally and reversely magnetised zones can be seen at southern "Blindtarmen" and at Terrassevig (west and east of Vikingebugt respectively) but a correlation with the Borgvig section further east, which is dominantly normally magnetised, has not been possible. Accepting the dip of approximately $2.5^{\circ} \mathrm{S}$, the section by Bredegletscher cannot be correlated with those to the north, since this section lies stratigraphically above the other profiles. The "grey series" at the top of the Bredegletscher section can be correlated stratigraphically with similar "grey series" on the adjacent nunataks and a similar magnetic direction fits this correlation.

As a result of the preliminary investigations in the area it seems possible to distinguish five normally and five reversely magnetised zones, though the correlation in most places is tentative due to the dispersion of the profiles. 


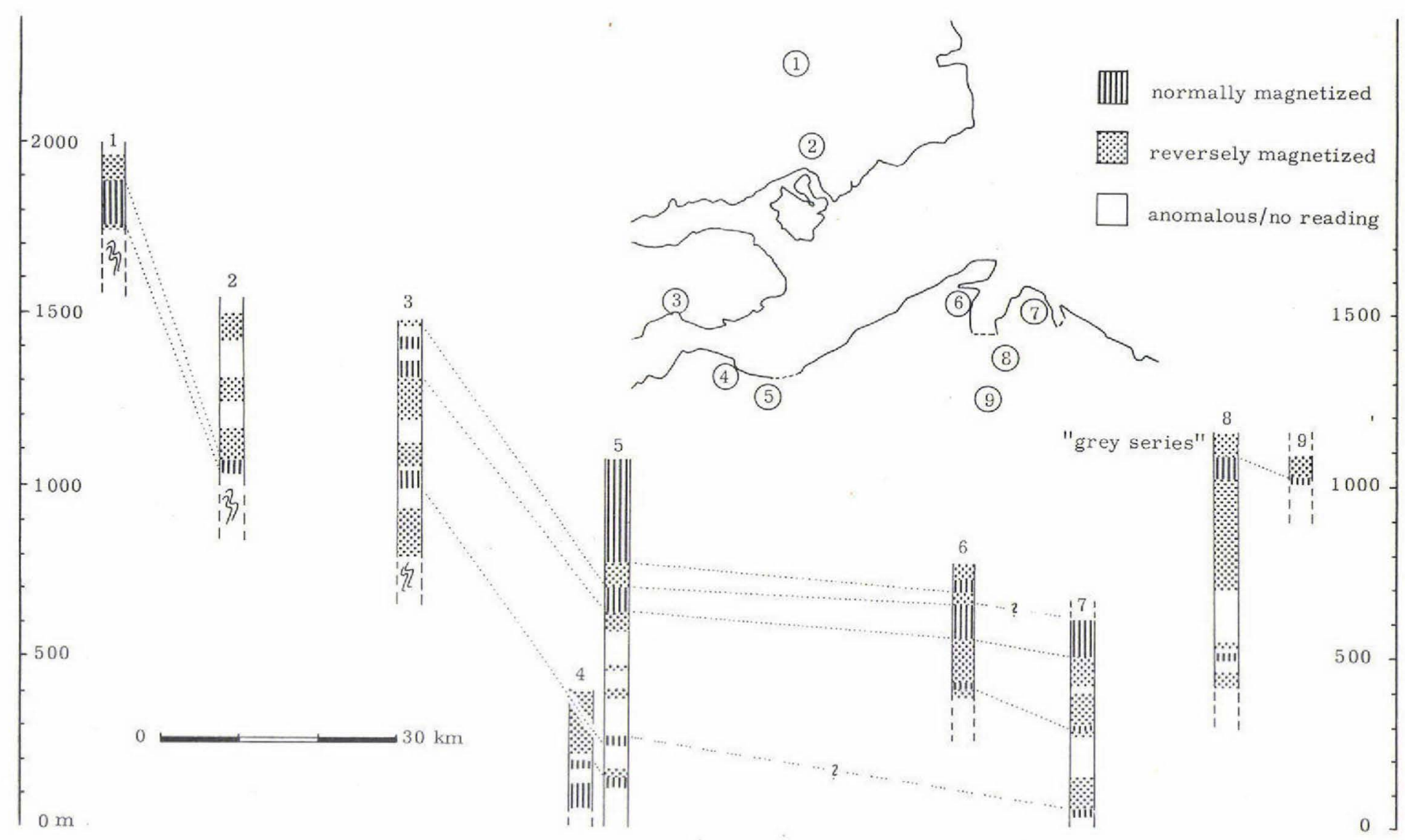

Fig. 8. Sections in the basalts showing zones of normal and reverse magnetisation. 


\title{
References
}

Aldinger, H. 1935: Geologische Beobachtungen im Oberen Jura des Scoresbysundes (Ostgrönland). Meddr Gronland 99, 1, $128 \mathrm{pp}$.

Spath, L. F. 1935: The Upper Jurassic invertebrate faunas of Cape Leslie, Milne Land. I. Oxfordian and Lower Kimmeridgian. Meddr Gronland 99, 2, $82 \mathrm{pp}$.

Walker, G. P. L. 1951: The amygdale minerals of the Tertiary lavas of Ireland. I. The distribution of chabazite habits and zeolites in the Garron plateau area, County Antrim. Mineralog. Mag. 29, 773-791.

\section{NOTES ON THE GLACIAL GEOLOGY OF EASTERN MILNE LAND, SCORESBY SUND, EAST GREENLAND}

\author{
Svend Funder
}

\section{Introduction}

During the summer of 1969 field work was begun with the aim of establishing a general chronology of Quaternary events in the Scoresby Sund region. This summer the work was concentrated on the eastern part of Milne Land (fig. 1).

The region under consideration is shown in fig. 9; it comprises a coastal zone of low rounded mountains $(400-600 \mathrm{~m})$ composed of crystalline rocks, and a central zone of high mountains $(1500 \mathrm{~m})$ of alpine topography where Tertiary basalts rest on a basement of crystalline rocks. South-east of a line from Mudderbugt to Charcot Havn the bedrock is Mesozoic sandstone. Milne Land is bordered to the east and south by the comparatively shallow (400-600 m deep) waters of Scoresby Sund and Hall Bredning; on all other sides this large island is bordered by over-deepened fjords (800-900 m deep - see hydrographic chart in Thorson, 1934). In the central part of Milne Land an ice cap - Puderne - is found.

Observations on the Quaternary geology of Milne Land were made during the expedition led by C. Ryder in 1891-92 (Bay, 1896). At the following other places in the Scoresby Sund region work on the Quaternary has been carried out: Jameson Land (Nordenskiöld, 1907), Kjove Land (Sugden \& John, 1965), Schuchert Dal (Cruikshank \& Colhoun, 1965; Schafer \& Hartshorn, 1965). Information on the Scoresby Sund region from written sources as well as from aerial photos has been compiled on the Quaternary Map of Greenland, 1:2 500000.

The present investigation is planned to be the first of a three-summer project which will also comprise studies in the coastal and in the interior parts of the re- 